\title{
A Study on the Relationship between Developing Countries and the Middle-Income Trap: A Narrative in the Zambian Perspective
}

\author{
Brian Kapotwe \\ Directorate of Research and Graduate Studies, University of Zambia, Lusaka, Zambia \\ Email: bkapotwe@yahoo.com
}

How to cite this paper: Kapotwe, B. (2021). A Study on the Relationship between Developing Countries and the Middle-Income Trap: A Narrative in the Zambian Perspective. Modern Economy, 12, 363-384.

https://doi.org/10.4236/me.2021.122019

Received: January 7, 2021

Accepted: February 23, 2021

Published: February 26, 2021

Copyright $\odot 2021$ by author(s) and Scientific Research Publishing Inc. This work is licensed under the Creative Commons Attribution International License (CC BY 4.0).

http://creativecommons.org/licenses/by/4.0/

\begin{abstract}
While the Middle-Income Trap (MIT) has gained popularity in Europe, Asia and America in the past 15 years, little data exists about its impact on Africa. This is because, until recently, Africa had recorded minimal economic growth. However, since the year 2000, several African countries have recorded rapid economic growth to attain middle-income status, but very few have transitioned to high-income levels. This study aimed to establish Zambia's standing regarding the MIT. A unit root model was used to test for income convergence between Zambia and the United States of America (US). In line with the study model, income convergence is equivalent to the absence of unit root in the natural log difference in per capita income between the US and Zambia. The Augmented Dickey-Fuller, Phillips-Perron test which accounts for serial correlation and GLS detrended augmented Dickey-Fuller test were used to test for the unit root. All tests identified unit root indicating the lack of GDP per capita convergence between Zambia and the US. These results indicate Zambia is at a high risk of falling into MIT. To break from the MIT, Zambia should diversify its economy and shift from input led growth to growth based on economic efficiency. The lack of sustained economic growth in Zambia is due to 1) the inability to identify new growth drivers at the middle-income stage, 2) failure to institute the required political and institutional reforms to sustain growth at MIC level.
\end{abstract}

\section{Keywords}

Middle-Income Trap, Convergence, Economic Growth, GDP Per Capita

\section{Introduction}

The Middle-Income Trap (MIT) is an inexorably well-known idea used to ex- 
amine the marvels of growth slowdowns of developing economies. Nevertheless, the term has no all-around acknowledged definition, which restricts its utilization in the monetary talk. Along these lines, the point of this article is to assist with building up an applied system for monetary examination, including the MIT idea. The transition from low to middle, and eventually, high-income status is an important economic development target for any developing country. Some countries transition quicker while others are stuck at one level. Most scholars have argued that innovation and increase in productivity at the country level are crucial to sustaining economic growth. The gradual development of an economy from a traditional resource-driven growth to growth based on economic efficiency depends on its ability to formulate and implement innovative economic policies. To achieve economic transformation, all advanced economies of today went through economic development stages, which, if understood, can provide useful lessons for Least Developed Countries (LDCs).

Economists have long explored why some countries grow faster than others do. According to the convergence hypothesis and the Solow-Swan model, poorer countries per capita income is expected to grow at a faster rate than in developed countries and that this would eventually lead to per capita income convergence. The models highlight that the convergence of income is due to better chances for growth available to developing countries such as technology from developed countries and higher returns on capital. Contrary to this hypothesis, many least developed countries have recorded minimal growth against advanced economies in the past century, raising questions about the validity of the convergence hypothesis. For instance, Paprotny (2021) tested for convergence between developing and developed countries. He found that economic progress was unevenly distributed, with East Asian and European countries converging the most against the US, while most African countries have diverged along with some American ones.

Economic literature on the MIT shows that once a country attains the MIC status, it experiences a slowed rate of economic growth and stagnates within the MIC category. The MIT is an economic development situation that arises in countries that experienced rapid economic growth to reach middle-income but then fail to transition to high-income status. The difficulty in this transition lies in the inability of a country to make "critical transitions" from the physical accumulation of factors to productivity-led growth via innovation (Kharas \& Kohil, 2011). In other words, the transition depends on the ability of countries to shift from merely importing goods and knowledge and imitating them to actually innovating (Kim, 1997).

\subsection{The Middle-Income Trap and Economic Growth Slowdowns}

Farah (2016) argues that the factors affecting growth at low-income and high-income levels can be different and should be taken on a case-by-case basis. According to the World Bank, there are currently 31 countries classified as Low-Income Countries (LICs). Unlike the LICs before 2000, today's LICs face 
numerous challenges including fragile economies, heavy reliance on agriculture-which further makes them vulnerable to climate change and extreme weather, Steinbach (2019). Further, their scope to boost external trade is limited by geography.

The factors accounting for economic growth slowdown at middle-income level are complex and require more research. Most of such studies have mainly focused on economies in Europe, Asia, and America. Mostly, this is because countries in these regions have recorded the highest economic growth rates in the last century. Several successful East Asian economies, such as Singapore and South Korea, have rapidly caught up with the United States in per capita income, and have reached an income level of high-income economies owing to their persistent and robust growth. China's economy has also shown remarkable growth since 1980 by adopting market-oriented reforms and opening to international trade (Lee, 2019).

In contrast to the rapid income convergence of these East Asian economies, several other lower and middle-income economies have stagnated. Many Latin American economies, including Brazil and Mexico, have not yet achieved highincome status (Lee, 2019).

\subsection{Middle-Income Trap in Africa}

Despite Africa's rich endowments, little data exists on the MIT. This is partly because, until recently, there has been extraordinarily little economic growth, especially in Sub-Saharan Africa. According to Dieye, out of 37 countries that remained low income from 1950 through 2000, 31 were in this region. Since 2005, 10 African countries have reached middle-income status, as compared with nine between 1973 and 2000 (Dieye, 2014). These countries have emerged and are now part of the fastest-growing economies in the world. These small middle-income countries (SMICs) represent a successful group that has experienced robust economic growth and sustained improvements across a broad range of development indicators. However, the IMF reports that the growth rates in many of these countries have been slowing in the past few years, even before the 2008-2009 financial crisis. For some of them, even though HDI indicators remain respectable, significant improvements have not been made since 2005.

The question then becomes whether past policies on intensive capital investment (capital deepening) have run their course and to what extent they have underpinned sustained gains in productivity driven by structural reforms that would support sustainable high growth over the medium term (IMF, 2016, Unlocking the Potential of Small Middle-Income States).

In addition, the continent continues to record the highest levels of poverty, inequality, and widespread economic stagnation. The growth slowdown reflects both the weaker global conditions and domestic constraints. Closer to Zambia, countries like Botswana, Lesotho, Namibia, and Swaziland are heavily exposed to 
the slowdown in the South African economy from trade channels and the decline in revenues from the customs union ( $\mathrm{Zhu}, 2016)$.

According to Mondi (2016), South Africa has experienced stagnating economic growth due to its low manufacturing output. To escape, it needs to change its industrial character. It must move into fabrication and high value-added manufacturing and design. Botswana has shown consistent economic performance over the years growing above the Sub-Saharan African average.

In the past ten years, however, Botswana's growth has fallen short of the rapid increase in GDP per capita observed in previous decades, especially in the 1970s and 1980s. While Botswana has achieved lower-middle-income status, to see further development and escape from the middle-income trap, it will need sped up reform. Greater investment and faster productivity growth will be needed to improve potential output, which has stagnated (Khan, 2019).

To sustain economic performance, African economies need to work towards economic diversification, increase production efficiency, and improve exports. The World Economic Forum has identified five risk factors threatening the sustained growth of Sub-Saharan economies including: 1) unemployment and underemployment; 2) underinvestment in infrastructure; 3) fiscal crisis; 4) political change; and 5) climate change.

\subsection{Zambia and the Middle-Income Trap}

Zambia presents a unique economic development situation. After starting as a Lower-Middle-Income (LMI) economy at independence in 1964, the country declined to Law-Income status for a long time before graduating again to Lower-Middle-Income Country (LMIC) status in 2010. Key questions around Zambia's economic growth are explored in this article. Will Zambia graduate to a higher income level or be trapped in the middle-income range or, in the most pessimistic scenario, even decline once again to low-income status? Here, it is important to see that even after graduating to low middle-income status in 2010, Zambia continues to be one of the 47 Least Developed Countries (LDCs) as of 2018 in the UN classification.

\section{Zambia's Economic Overview 1964-2018}

As seen from Figure 1 below, Zambia's economic growth was affected by the country's economic systems in the period between 1964-1990 and 1991-2018. During the command, economic growth was affected by massive state intervention that saw the nationalization of key institutions and enterprises across various sectors. This affected its profitability and output per worker, despite the country's abundant physical and human resources. Introducing multiparty democracy and liberation of the economy after 1991 led to the recovery of the Zambian economy, especially after the year 2000.

The continued economic growth after the year 2000 led to Zambia's attainment of the middle-income status. Despite this, Zambia continues to experience huge economic setbacks. The country's overall economic growth rate has 


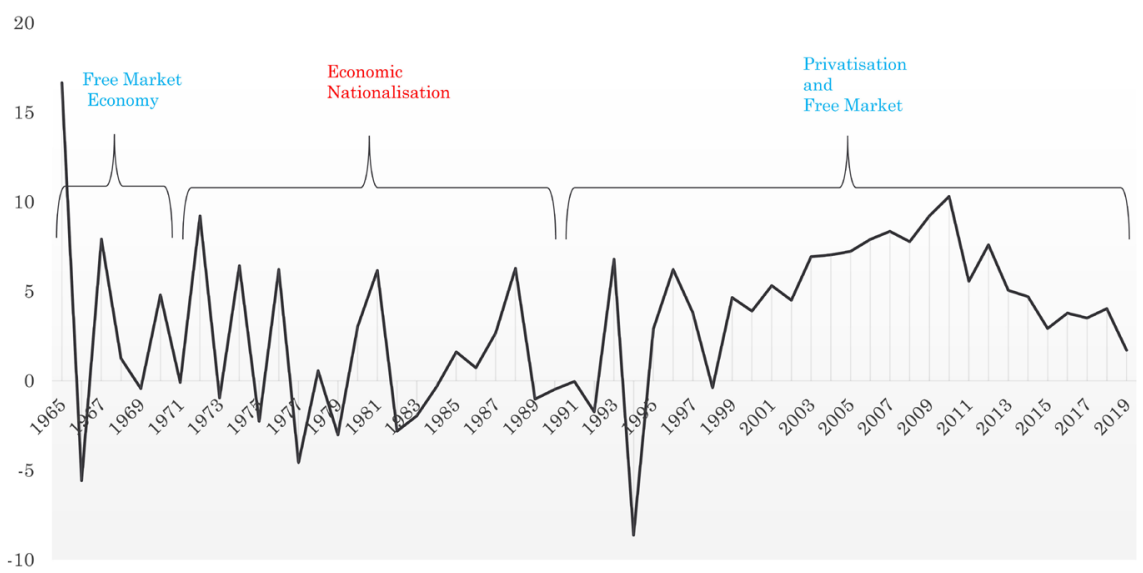

Figure 1. Zambia's GDP growth percentage per annum (1965-2019). Source: Author based on World Bank data.

reduced from $4.9 \%$ in 2014 to $1.7 \%$ in 2019 . Before the recent outbreak of COVID-19, the IMF (2019) Article IV consultation with Zambia estimated that Zambia's growth rate will decline further to a meagre $1.5 \%$ by 2024 . The COVID-19 (coronavirus) pandemic has exacerbated Zambia's macroeconomic vulnerabilities and the World Bank projects that Zambia's economy will contract by about $4.5 \%$ in 2020 .

While the share of industry to GDP has increased from $30.9 \%$ in 2008 to $36.2 \%$ in 2018 , the secondary sector has been affected by the rapid decline in the growth of the primary sector-agriculture. Agriculture's share of GDP has reduced from $11.45 \%$ in 2008 to $2.58 \%$ in 2018 . The lack of progress in the key variables that affect Zambia's income level and the absence of the required economic transition in the middle-income context may predispose it to MIT. This study is relevant for Africa and Zambia, as there are currently limited studies on the MIT in the region.

\section{Conceptual Framework for the Middle-Income Trap}

Current economic literature defines MIT in absolute and relative terms. In absolute terms, Eichengreen et al. (2012a) define the MIT as a growth slowdown in emerging market economies. According to their definition, a country experiences a growth slowdown if, and only if: 1) the seven-year average growth rate of real per capita income is $3.5 \%$ or greater prior to; 2 ) after, the growth rate is lower by at least two percentage points; and 3) the per capita income is greater than $\$ 10,000$. Eichengreen et al. (2012b) concluded that growth slowdowns typically occur at two different per capita income ranges, namely between $\$ 10,000$ and $\$ 11,000$, and between $\$ 15,000$ and $\$ 16,000$. Relative MIT definitions focus on the (failed) catching-up process (relative to a developed country such as the US or Japan). Woo et al. (2012) constructed a Catch-Up Index (CUI), in which values are expressed as a percentage of the US per capita income by using population and GDP data from Maddison data base, while the latter was measured in 
1990 Geary-Khamis dollars. According to the authors, middle-income countries have a CUI between $20 \%$ and $55 \%$.

Woo et al. (2012) based their decision to use these thresholds on the fact that most Western European countries belong to the high-income group, whereas most Sub-Saharan countries are low-income economies.

In both approaches, the measurement of the MIT requires a measurement of (relative) income per capita based on the World Bank classification. The World Bank classifies countries based on their level of absolute Gross National Income (GNI) per capita. Effective July 2019, the updated country classification thresholds (in US dollars) are:

- Lower-middle income: US\$1026 - US\$3995;

- Upper-middle income: US $\$ 3996$ - US $\$ 12,375$;

- High income: >US $\$ 12,375$.

New thresholds are determined at the start of the World Bank's fiscal year in July and remain fixed for 12 months, regardless of subsequent revisions to estimates. Several economists have used GDP per capita to define and analyze MIT. In most studies, the analysis has focused on the minimum number of years required for a country to transition from one income group to another and the rate of GDP per capita growth. Felipe, Abdon, \& Kumar (2012) calculated the threshold number of years for a country to be in the MIT as maximum 28 years for Lower-Middle-Income countries and 14 years for up Middle-Income Countries. To avoid falling in the MIT, a country must record a GDP per capita growth rate of 4.7 per annum for Lower-Middle-Income Countries and 3.5 per annum for Upper-Middle-Income Countries.

\subsection{Causes of the Middle-Income Trap}

In line with the definitions from the relative and absolute terms, there are two main reasons for the MIT including failed catching-up process and political and institutional failures.

\subsubsection{Lack of Strong Economic Convergence}

The convergence hypothesis explains the reasons for the rapid growth around Law-Income Countries (LICs) based on the neoclassical Solow (1956) growth models. The models predict that due to diminishing marginal product of capital, poor countries can grow faster to catch-up with the rich countries. According to Ito (2017), the middle-income trap is because of failing to make the jump from the middle-income convergence path to the high-income convergence path. Hence, growth convergence results in a steady state that is lower than the steady state of the advanced economies (or the US). When an economy's growth rate is equal to the long-run per capita growth rate of the US, the gap with the US in terms of per capita income (position on the horizontal axis) stays constant. When an economy follows the middle-income convergence path to the steady state, the income gap remains permanent, and the economy is said to be stuck in the middle-income trap. In fact, it is not a trap, but a failure to adopt innovation 
and progress in using technology.

For example, while Thailand is approaching an average per capita growth rate of $2 \%$, it may fail to catch up to the per capita income level of the US unless it makes a shift toward innovation. Based on the above, MIT is largely the result of a country's inability to continue moving from low value-added to high value-added industries. The advantages of low-cost labor and imitation of foreign technology can disappear when middle- and upper-middle-income levels are reached (The Economist, 2011).

According to Kharas and Kohli (2011) most countries fall into MIT because they fail to adopt new growth strategies once they reach middle-income status. They argue MICs need to focus more on demand-side strategies rather than on supply side strategies, the latter of which enables successful transition from low to middle-income but not from middle to high-income. With escalating wages, middle-income economies lose their cost competitiveness in exports. New strategies are thus needed to develop new products, processes, and markets. Pierre and Agenor (2016) identified several factors as reasons for the growth slowdown and weak economic convergence:

1) Diminishing returns on capital;

2) Exhaustion of cheap labor and imitation gains;

3) Insufficient quality of human capital;

4) Inadequate contract enforcement and intellectual property protection;

5) Distorted incentives and misallocation of talent;

6) Lack of access to advanced infrastructure;

7) Lack of access to finance.

\subsubsection{Political and Institutional Failures}

Doner \& Schneider (2016) identified political and institutional challenges that would contribute to MIT. They state that the upgrading of reforms necessary to maintain and move out of the middle-income status are difficult. Because of their complexities, implementing such reforms requires institutions to coordinate, to monitor and reconcile the interests of multiple actors, and to help provide specialized information.

Such institutions operate at multiple levels, ranging from overall sectoral coordinating institutes and public-private consultative councils, to judicial offices for effective contract enforcement and patent protection, to agencies specializing in areas such as innovation financing, testing and standards, R\&D promotion, and vocational training. Creating such institutions is difficult because they require both horizontal coordination among state agencies, among firms, and between public and private actors, and vertical coordination of many providers, such as highly trained researchers, judges, teachers, curriculum developers, and test engineers, each of whom plays important roles in long implementation chains. This study focuses on causes of the middle-income trap that are more related to Lower-Middle-Income Countries (LMICs) in Africa. A deeper analysis on the sources of growth and the factors that may influence the economic 
growth of a newly classified MIC will be done. Unlike poverty traps, middle-income traps will occur after a country has experienced rapid growth and to a larger extent even improved the quality of life of its population. A critical element for sustaining growth in a middle-income country is the identification of the new growth drivers and an analysis of whether the conditions to improve and innovate are in place. Figure 2 presents the conceptual framework of the MIT.

In line with the conceptual framework above, a country can easily reach middle-income status due to higher returns on capital but may struggle to transition to high-income status. The difficulty in this transition lies in the inability of a country to make "critical transitions" from the physical accumulation of factors to productivity-led growth via innovation (Kharas and Kohli, 2011). In other words, the transition depends on the ability of countries to shift from merely importing goods and knowledge and imitating them to actually innovating. As MIT is largely dependent on GDP per capita, there is a need to identify the factors that affect GDP per capita and the economic structure of a low-income country as it transitions to MIC status. As the MIT idea has gotten more famous among financial experts, media, and policymakers, some have begun testing its legitimacy, highlighting an absence of strong exact proof and hypothetical establishment. The discussion was opened not by a logical paper yet by an article distributed by The Economist (2011) named "The Middle-Income Claptrap". In the article, it was brought up that maybe there was no explanation to single out the center pay levels since potential development traps could be found at any pay level. An exuberant conversation followed among analysts who tried the idea exactly.

Most cited in such manner are maybe Im and Rosenblatt (2013), who brought up that, although the MIT is helpful for directing arrangement conversation, there is no factual proof of its reality. Im and Rosenblatt (2013) discovered little proof supporting the presence of MIT. The creators investigated both the outright and relative limits of the snare. With temporary framework examination,

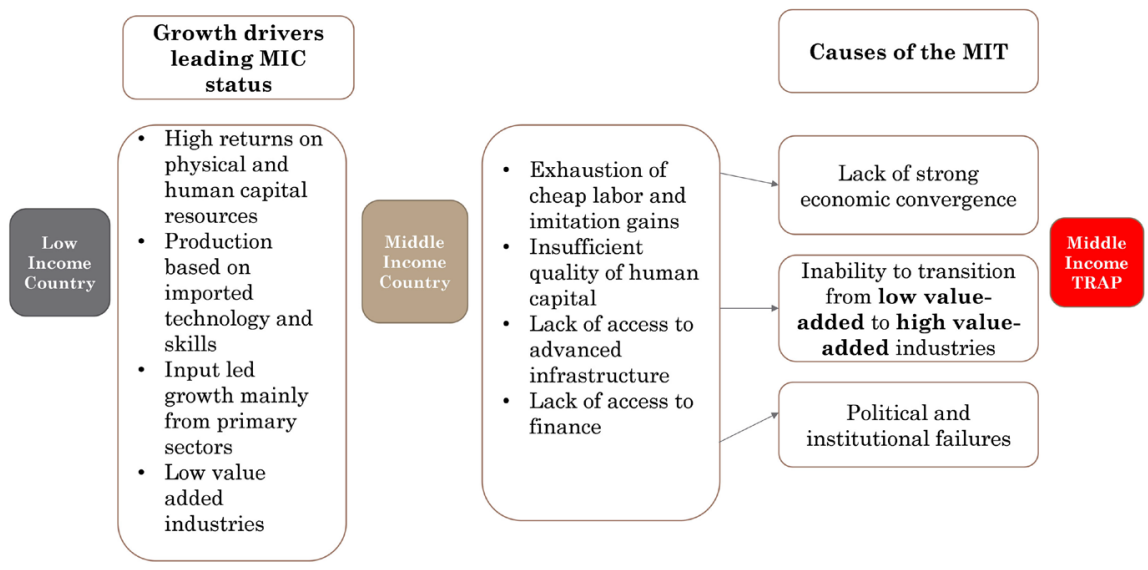

Figure 2. The conceptual framework of the Middle-Income Trap (MIT). Source: Author. 
they discovered little help for the thought. Nonetheless, they likewise focused on that the idea is valuable for directing arrangement conversations since it precisely characterizes the challenges looked by nations at that phase of improvement. Moreover, they noted that the MIT idea stood out for economists to the predetermined number of middle-income nations that had been fruitful in accomplishing a created nation status.

Notwithstanding, they additionally proposed that a specific measure of authenticity ought to be added to the conversation. They called attention to that the recognizable proof of the little gathering of quickly developing center pay escapees could prompt a type of "anomaly love". The goal of ceaselessly developing at $7 \%$ or $10 \%$ could prompt unreasonable arrangements that eventually would make the snare like an example of dreary development that center pay nations are attempting to keep away from in any case. Gradualism might be more feasible and safer, particularly for upper center pay nations.

In their latest examination, Felipe, Kumar, and Galope (2014) additionally questioned the presence of the MIT. They proposed that the idea is dangerous on the grounds that it isn't very much characterized and has not been concentrated hypothetically. They tried the presence of MIT and didn't discover adequate proof that it did exist. They referred to the underlying illustration of a gathering of nations introduced in Gill and Kharas (2007) to push that while the East Asian economies climbed across pay bunches quicker, this didn't mean that Latin American nations didn't climb. Indeed, the creators contended, they did, yet at a slower speed.

Bulman, Eden, and Nguyen (2014) were likewise wary of the presence of the MIT. They contended that nations that used to develop quickly (when all is said and done) kept on developing quickly furthermore, didn't stall out at a particular degree of pay. Nonetheless, they likewise noticed that some centers pay nations stayed stale with low development of relative pay, furthermore, that, overall, progressing from a center pay to a major league salary nation is testing.

Pritchett and Summers (2014) likewise recommended that the MIT makes minimal monetary sense. The creators contended that while an ever-increasing number of nations are supposed to be stuck in MIT, this simply mirrors the mean inversion of their development rates. Thus, some policymakers may see their homegrown economies caught and they may appropriately actualize arrangements to address the difficulties of the 21st century, while for a few nations, there are yet nineteenth century issues to address.

The creators singled out two specific reasons why the MIT idea was exaggerated. To begin with, they brought up (likewise to Felipe, Kumar and Galope, 2014) that thoughtfully it is troublesome to comprehend what MIT really implies. Second, they gave new experimental proof that quick development is a considerably more impressive indicator of the probability of deceleration than the degree of pay in that capacity.

Then again, Robertson and Ye (2013) discovered solid, exact proof of the presence of MIT. They gave their own, measurably testable meaning of the mar- 
vel that the MIT can be considered as a circumstance when long haul pays estimates to show no propensity to meet to nation levels or wander underneath the middle-income band. They found that the development directions of an enormous number of middle-income nations were steady with what might be normal if they were in MIT. Therefore, the creators contended that the idea confronts investigation in a measurable sense.

\section{Significance and Limitations of the Study}

\subsection{Significance}

The study provides new information for government and other stakeholders on suitable growth strategies for newly classified lower middle-income countries. It further highlights Zambia's standing with respect to the MIT.

\subsection{Limitations of the Study}

Lack of research on the impact of the MIT in Africa and Zambia in particular makes it difficult to assess Zambia's exposure to the trap and to draw lessons on how to avoid it if trapped. Understanding how MIT has affected other countries in different contexts is key to defining successful economic growth strategies. For instance, several countries in Asia and Europe have recorded rapid economic growth owing to the availability of extensive studies on the factors leading to growth slowdown and the MIT.

\section{Research Question and the Objectives of the Study}

\subsection{Research Questions}

In line with the Convergence hypothesis, is there economic convergence between high-income countries like the US and that of Zambia?

\subsection{Objectives of Study}

1) To understand Zambia's economic growth trends and the factors affecting its economic growth rate.

2) To determine Zambia's standing with respect to the MIT.

\section{Literature Review}

Despite its common use in economic literature, the term Middle-Income Trap does not have a universally agreed definition. As such, different scholars have applied it differently. Despite the differences in its application, common elements stand out as follows: 1) a stagnation in a country's economic growth when it reaches middle-income range. In this case, the MIT is the inability of a country to sustain its earlier growth momentum but stagnates or even declines to low-income status; 2) a shift in the economic structure and drivers of economic growth.

The MIT is caused by a country's failure to transition and address the economic challenges that characterized a MIT. This section presents various studies 
about MIT, mainly from Europe and Asia.

Kang \& Paus (2020) reviewed various literature on the political economy of the Middle-Income Trap and the challenges of advancing innovation capabilities in Latin America, Asia and beyond. They made three main conclusions as follows: 1) the development of domestic productive capabilities is critical for upgrading and developing broad-based innovation that may translate into higher productivity growth; 2) The interaction of international with domestic factors changes over time and may exacerbate domestic innovation challenges; and 3) the nature of the interworking between the government and actors in the private sector is crucial for understanding the advancement of innovation capabilities or lack thereof.

Arezki, Fan, \& Nguyen (2019) documented the existence of a "Middle-Income Trap" for the Middle East and North Africa region and contrasted the evidence with that of the East Asia and Pacific region. The results are two-folds. First, non-parametric regressions show that the average rate of economic growth in the Middle East and North Africa has not only been significantly lower than that in the East Asia and Pacific region, but it has also tended to drop at an earlier level of income.

Second, econometric results point to Middle East and North Africa having experienced a relatively slow pace of technology adoption in general-purpose technologies and that a slower adoption pace of technology is associated with lower levels of economic growth. The paper concludes that barriers to the adoption of general-purpose technologies related to the lack of contestability in key sectors constitute an important channel of transmission for the Middle-Income Trap.

Konya, Karaçor, \& Yardimci (2018) in their paper entitled "The Middle-Income Trap: An Assessment in Terms of the Turkish Economy" aimed to evaluate whether Turkey is in a Middle-Income Trap or not. The look at the effect of manufacturing industry's share in GDP, schooling rate in higher education and the share of domestic savings in GDP on per capita income level was examined by time series analysis in this context and arguments related to the Middle-Income Trap were made.

The relationship between the variables in the study was analyzed by Engle Granger cointegration and Engle Granger causality analysis methods. According to the obtained results, a long-term relationship was found between the variables used. The share of the manufacturing industry within GDP occurred as the cause of the per capita income level. No causality relationship was found between the other variables. According to the evaluations, it is determined that Turkey is not in the Middle-Income Trap however it has the risk of having a Middle-Income Trap.

Traps, Agenor (2016) provided an overview of the recent analytical and empirical literature on the Middle-Income Trap. In the first section, the paper examines the descriptive and statistical evidence on these traps. The second section discusses the various arguments that have been put forward to explain the exis- 
tence and persistence of Middle-Income Trap. These arguments include diminishing returns to physical capital, exhaustion of cheap labor and imitation gains, insufficient quality of human capital, inadequate contract enforcement and intellectual property protection, distorted incentives and misallocation of talent, lack of access to advanced infrastructure, and lack of access to finance, especially in the form of venture capital. The third part considers public policies aimed at avoiding and escaping from Middle-Income Trap. The concluding part identifies several directions in which the empirical and theoretical literature could fruitfully evolve.

Lee and Li (2014) discussed the possibility of China falling into the Middle-Income Trap in terms of three checkpoints: innovation capability, world-class big businesses, and inequality. Based on these criteria, Keun Lee makes the following conclusions: First, China has increasingly become innovative and thus differs from other middle-income countries; Second, China has many successful big businesses, a number disproportionate to its size. Third, China faces great uncertainty in terms of inequality.

Although several signs show that the Kuznets curve will come to represent China, as noted by the gradual reduction of surplus labor and rising wage rates starting in the coastal provinces, the Chinese are now facing new sources of inequality such as wealth (including financial and real estate assets) and non-economic factors such as corruption.

Felipe, Abdon, \& Kumar (2012) came up with a working definition of the Middle-Income Trap. They calculated the threshold number of years for a country to be in the Middle-Income Trap: a country that earns lower to middle-income (reaching $\$ 2000$ per capita income) has to attain an average growth rate of per capita income of at least $4.7 \%$ per annum to avoid falling into the Lower-Middle-Income Trap (i.e., \$7250, the upper-middle-income threshold); and a country that earns upper-middle-income (reaching $\$ 7250$ per capita income) has to attain an average growth rate of per capita income of at least 3.5 percent per annum to avoid falling into the Upper-Middle-Income Trap (i.e., $\$ 11,750$, the high-income level threshold).

Avoiding the Middle-Income Trap is, therefore, a question of how to grow fast enough to cross the lower-middle-income segment in at most 28 years, and the upper middle-income segment in at most 14 years. Aiyar et al (2013) examined the Middle-Income Trap as a special case of growth slowdowns, which are identified as large sudden and sustained deviations from the growth path predicted by a basic conditional convergence framework. They then examine their determinants by means of probit regressions, looking into the role of institutions, demography, infrastructure, the macroeconomic environment, output structure and trade structure. Two variants of Bayesian Model Averaging are used as robustness checks. The results including some that indeed speak to the special status of middle-income countries are then used to derive policy implications, with a particular focus on Asian economies.

Lee (2019) investigated the economic growth experiences of middle-income 
economies over the period of 1960-2014 focusing on two groups of countries. The "convergence success" group includes middle-income economies, which graduated to a high-income status or have achieved rapid convergence progress. While an economy in the "non-success" group experienced growth deceleration and failed to advance to a high-income status, the paper defines such episodes as the "Middle-Income Trap". The probit regressions show that "convergence successes" tend to maintain strong human capital, a large working-age population ratio, effective rule of law, low prices of investment goods, and high levels of high-tech exports and patents. Adding to unfavorable demographic, trade and technological factors, rapid investment expansion, hasty deregulation and hurried financial opening could cause the "non-successes" to fall into the Middle-Income Trap.

Leven (2019) used the Rostow's classification of the stages of economic development to assess MIT. The paper focused on Rostow stages three and four, where moving from labor intensive, import and foreign direct investment (FDI) driven growth to reliance on high value-added output and exports with embedded high content of capital and technology can render sustainable long-term growth problematic.

To examine MIT for Poland, which has relied on relatively low labor costs, imported technologies, funding from the European Union and FDI to attain middle-income status. A recent slowing in Poland's growth may signal that it has exhausted some of these growth factors and is more vulnerable to MIT.

To assess this vulnerability, we analyze changes in Poland's factor productivity, investment patterns, FDI, labor force educational attainments, new technology/product development, imports, export diversification, product complexity, and other factors. We conclude that certain conditions consistent with MIT are gaining importance in Poland and represent a challenge to its future economic growth (Leven, 2019).

Aviliani, Siregar, \& Hasanah (2014) used descriptive statistics in their paper titled "Addressing the middle-income Trap: Experience of Indonesia and found that more than 30 countries were in MIT. Some countries in Africa are even experiencing a low-income trap. Between 1970 and 2011, Indonesia was in a transition condition of a low-income to middle-income economy. Indonesia has begun to face constraints that would inhibit the sustained growth, particularly on the supply side of the economy. It is better to do the anticipatory actions that can strengthen the economy's fundamentals to avoid MIT.

The estimated regression model used in this study indicates that the increase in current national income is affected by the previous national income and the share of gross fixed capital formation to GDP. So, to avoid MIT, the government of Indonesia should prioritize investment for developing growth centers as well as for improving human resources and technology application.

Albuquerque (2019) evaluated the alternation between catching up periods and falling behind periods in Brazilian economic history, with data from 1870 to 2016. This alternation expresses the middle-income trap. They presented a ten- 
tative theoretical framework, suggesting a two-dimensional process, with external forces (basically technological revolutions in leading countries) increasing the gap between Brazil and the leading economy, and internal forces (basically planned or unplanned internal efforts, especially industrial policies) reducing that gap. The historical origins of this long-term middle-income trap are discussed, with a special focus on the role of income inequality.

Flaaen, Ghani, \& Mishra (2013) discussed MIT in the context of Malaysia. The authors argue that countries trapped in the middle-income conundrum will need to expand their "modern" sectors. Traditional sectors with low productivity must shed labor, and high-productivity modern sectors (be they in goods or services) must hire more labor if they want to grow.

Im and Rosenblatt (2013), thus, built two progress frameworks utilizing two elective arrangements of relative pay gatherings (with the US as the benchmark nation). In the two cases, they separated nations into five relative pay gatherings. In the primary arrangement of change frameworks, nations were named follows those with salaries not exactly 0.15 of the US pay; those somewhere in the range of 0.15 and 0.30 of the US pay; those between 0.30 and 0.45 of the US pay; those somewhere in the range of 0.45 and 0.60 of the US pay; and those with pay above 0.60 of the US levels. In the subsequent set, the order was as follows: nations with a pay under $1 / 16$ of the US pay; those between $1 / 16$ also, $1 / 8$ of the US pay; those between $1 / 8$ and $1 / 4$ of the US pay; those between $1 / 4$ and $1 / 2$ of the US pay; and those with pay over $1 / 2$ of the US level.

Different from other studies, this article tested for MIT by using both convergence analysis and per capita income thresholds. By doing so, the study not only establishes whether Zambia is in the MIT but also highlights the country level factors affecting Zambia's income levels and provides recommendations on how to sustain growth as LMIC. The study tested for convergence between Zambia and the US. While the rationale for choosing US as the benchmark was done by the following studies, with fascinating commitments in regard to this classification were made by Agenor and Canuto (2012), Bukowski, Halesiak and Petru (2013), Im and Rosenblatt (2013), Jones (2002), and Robertson and Ye (2013).

In these articles, the US is utilized as the benchmark nation since:

1) It is a high-income nation.

2) For some specialists, it speaks to the mechanical wilderness of the world.

3) And it is seen as a nation with a drawn-out adjusted development (Jones, 2002).

The study tested the convergence hypothesis by comparing Zambia's GDP per capita income with that of the US. Eighteen countries mainly from Sub-Saharan Africa and two Asian Countries were included in the comparison with the US.

This is important to establish Zambia's standing in the sub-region when all sampled countries are compared to the US. This approach is based on the unit root model by Furuoka and Pui et al. (2019).

They analysed the MIT and economic growth slowdown using a unit root model. They proposed a new systematic test procedure for MIT and they em- 
pirically tested this procedure using one high-income country and 12 middle-income countries. According to Furuoka and Pui et al. (2019) and in line with existing literature (Bernard and Durlauf, 1996; Oxley and Greasley, 1997), income convergence between high-income country $i$ (US) and middle-income country $j$ (Zambia) would take place if the long-term forecasted per capita income in high-income country $i$ and middle-income country $j$ are equal, that is:

$$
\lim _{k \rightarrow \infty} E\left(y_{i, t+k}-y_{j, t+k} \mid I_{t}\right)=\lim _{k \rightarrow \infty} E\left(I G_{i j, t+k} \mid I_{t}\right)=0
$$

where $E$ is the expectation operator; $I_{t}$ is available information at year $t, I G_{i j, t}$ is income difference between country $i$ and country $j$ in year $t, y_{i, t}$ is a natural $\log$ of real per capita income in country $i$; and $y_{j, t}$ is a natural log of real per capita income in country $j$. In this context of income convergence framework, the MIT could be examined by testing the following null hypothesis:

1) $\mathrm{H}_{\mathrm{MIT}}^{0}$ : There would be an absence of income convergence between highincome country $i$ and middle-income country $j$.

The alternative hypothesis could be formulated as:

2) $\mathrm{H}_{\mathrm{MIT}}^{1}$ : There would be a presence of convergence between high-income country $i$ and middle-income country $j$.

From an applied econometric perspective, the absence of income convergence could be equivalent to the presence of unit root in the natural log difference in per capita income between high-income country $i$ and middle-income country $j$.

Similarly, the presence of income convergence could be equivalent to the absence of unit root in the natural log difference in per capita income between high-income country $i$ and middle-income country $j$. In this context of the unit root framework, the MIT could be examined by testing this modified null hypothesis:

1) $\mathrm{H}_{\mathrm{MIT}}^{0}$ : There would be a presence of unit root in the time-series of the income difference between high-income country $i$ and middle-income country $j$.

Furthermore, the alternative hypothesis also could be re-formulated as:

2) $\mathrm{H}_{\mathrm{MIT}}^{1}$ : There would be an absence of unit root in the time-series of the income difference between high-income country $i$ and middle-income country $j$.

The presence of the MIT would be substantiated if the unit root test would identify the presence of unit root in the time-series of income difference. Alternatively, the absence of the MIT would be substantiated if the unit root test would identify the absence of unit root in the time-series of income difference.

\section{Results and Discussion}

\section{Economic Convergence Test}

In line with step 1 of the study's methodology, the test for economic convergence against the US gives an indication whether the growth of Zambia's GDP 
per capita is on the right convergence path. Figure 3 below shows the trend in the growth of the GDP per capita log differences relative to the US for all the 18 countries that were used in this study, spanning from 1960 to 2019.

The variables were generated by converting all the GDP per capita to natural logarithm (Growth) of the 19 countries that were included in the study then subtracting the natural logarithm of each of other 18 countries from the natural log of GDP per capita of the US. The US was used in this case as the benchmark to assess whether the comparable countries have been stagnant relative to the US or not.

The results presented in Figure 3 show that the growth in GDP per capita of 15 out of 18 countries has been diverging from that of the US (baseline standard in blue on the graph). Since 1960, Zambia's growth in GDP per capita has been deteriorating relative to the US. Amongst the 18 countries that were included in this study, Burundi had the lowest GDP per capita growth relative to that of the US.

In 2019, Burundi's growth in per capita GDP was 5.6\% below that of the US from $4.3 \%$ in 1960, with an average of $4.9 \%$ below the U.S between 1960 and 2019. Furthermore, Figure 3 shows that growth in GDP per capita among the sampled Sub-Saharan has been deteriorating since the 1980s compared to the US except for Botswana. Interestingly, Singapore is the only country whose GDP per capita has surpassed that of the US since 2010. Thailand is another country whose growth in GDP per capita has significantly improved relative to that of the US, from $3.4 \%$ in 1960 to $2.1 \%$ in 2019 .
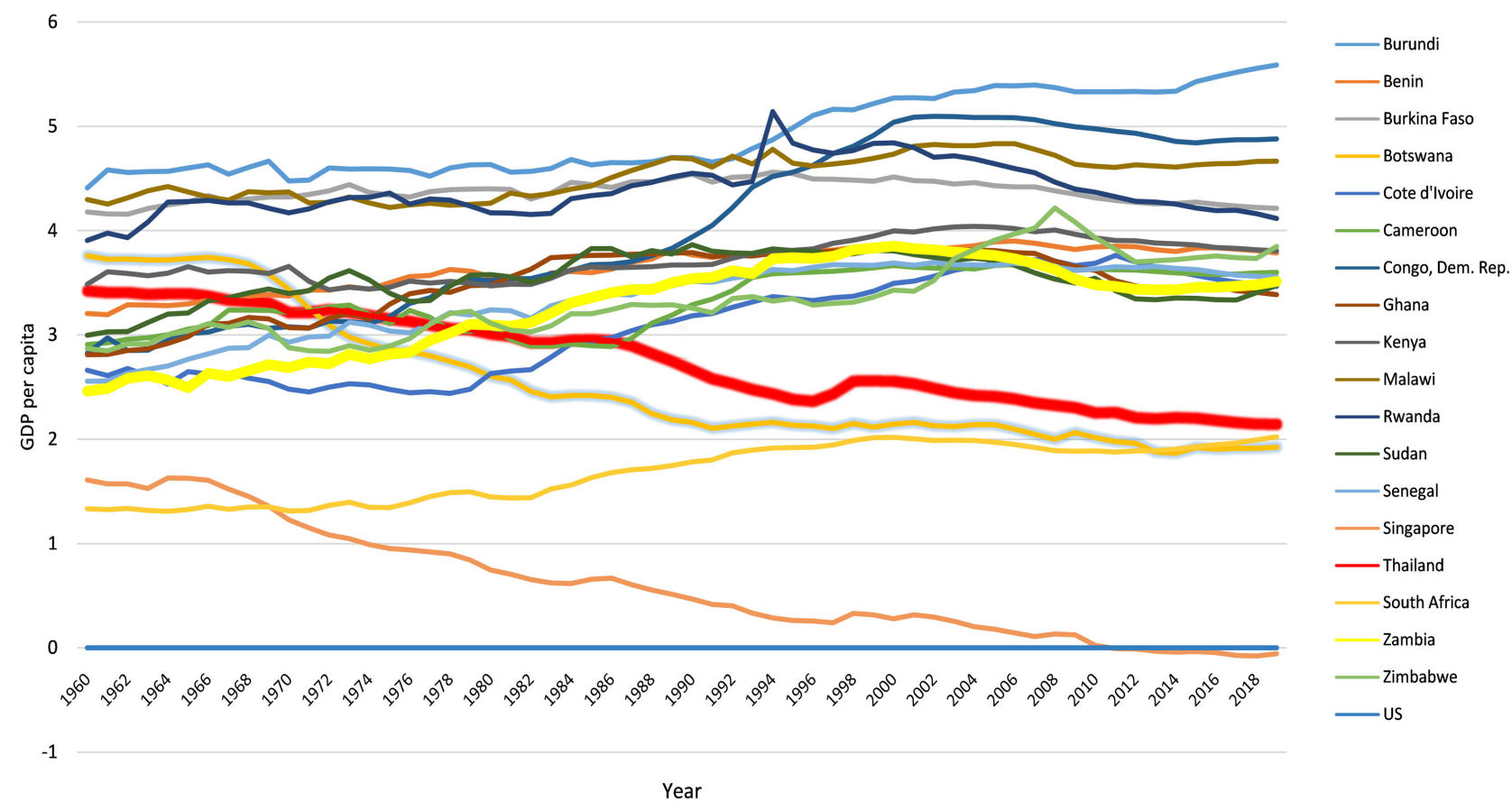

Figure 3. Annual GDP per capita growth rate relative to America. Source: Author (based on World Bank data). Zambia represented by the yellow bold line; US represented by the blue straight line at zero. 
Table 1 presents the results based on the convergence hypothesis, which was done by comparing Zambia's GDP per capita income with that of the US and then extended to the growth in the GDP per capita for sampled LMICs. For each of the18 countries, their natural logarithm of GDP per capita was subtracted from that of the US and then these differences were subjected to stationary tests.

To test for the presence of the unit root, three tests were employed which are Augmented Dickey-Fuller, Phillips-Perron test which account for serial correlation and GLS Detrended Augmented Dickey-Fuller test. The results show that the differences in the natural logs of GDP per capita for the countries that were sampled have a unit root. In line with the study model (step 1) and from an applied econometric perspective, the absence of income convergence could be equivalent to the presence of unit root in the natural log difference in per capita income between the US and the sampled countries.

From the above analysis, it can be concluded that Zambia is in the MIT. This conclusion is qualified by Figure 3, which shows the direction of Zambia's growth (in bold yellow line) relative to the US (blue line at the base). Unlike Singapore and Thailand, Zambia's GDP per capita is diverging from that of the US together with the rest of the other sampled countries throughout the study period. As highlighted in MIT Review of Related Literature, the lack of sustained economic growth at middle-income level is due to several factors including, 1) the inability to identify new growth drivers at middle-income stage; 2) failure to institute the required political and institutional reforms necessary to sustain growth at MIC level. In line with the conclusions of Kharas and Kohli (2011), many countries fall in the MIT due to their failure to adopt new growth strategies at middle-income level. The continued reliance on copper and inability to diversify the economy from heavily relying on copper has mainly contributed to this.

When Zambia's GDP per capita growth is analysed for 1970-2018, key conclusions can be made which can provide insight into the country's vulnerability to the MIT.

As seen in Figure 4 above, the country has experienced stagnating economic growth right from independence in 1964 and reducing GDP per capita income growth just a few years after LMIC classification in 2010. Such long-term economic stagnation explains the problem of MIT. As seen in Figure 4 above, the

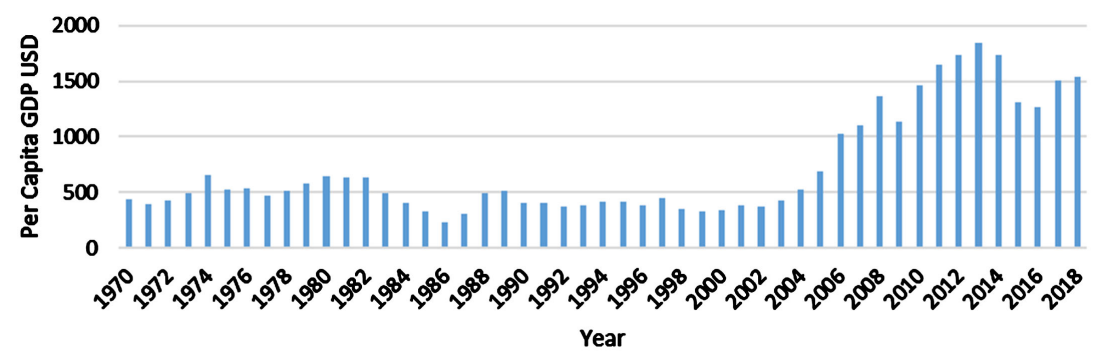

Figure 4. Zambia’s GDP per capita 1970-2018. Source: Author based on World Bank data. 
Table 1. Test for the presence of the income trap using the unit root test.

\begin{tabular}{|c|c|c|c|c|c|c|c|}
\hline \multirow{2}{*}{$\begin{array}{c}\text { TEST } \\
\text { Country }\end{array}$} & \multicolumn{2}{|c|}{$\mathrm{ADF}$} & \multicolumn{2}{|c|}{ Phillip Perron } & \multicolumn{2}{|c|}{ GLS-ADF test } & \multirow[b]{2}{*}{ Conclusion } \\
\hline & $\begin{array}{c}\text { Level } \\
\text { P-Value }\end{array}$ & $\begin{array}{c}\text { Lag } \\
\text { (SIC based) }\end{array}$ & $\begin{array}{c}\text { Level } \\
\text { P-Value }\end{array}$ & Bandwidth. & & $\begin{array}{c}\text { Lag } \\
\text { (SIC based) }\end{array}$ & \\
\hline Burundi & 0.7161 & 0 & 0.7146 & 3 & -1.77 & 0 & Unit root \\
\hline Burkina Faso & 0.9851 & 2 & 0.9094 & 8 & -1.48 & 0 & Unit root \\
\hline Benin & 0.3981 & 0 & 0.5198 & 1 & -2.10 & 0 & Unit root \\
\hline Botswana & 0.9592 & 0 & 0.9446 & 4 & -0.65 & 0 & Unit root \\
\hline Cote d'Ivoire & 0.7833 & 2 & 0.7126 & 4 & -1.30 & 2 & Unit root \\
\hline Cameroon & 0.2919 & 4 & 0.6967 & 4 & -2.65 & 4 & Unit root \\
\hline Ghana & 0.9842 & 0 & 0.9864 & 3 & -0.12 & 0 & Unit root \\
\hline Congo DR & 0.8805 & 2 & 0.9608 & 4 & -1.60 & 2 & Unit root \\
\hline Kenya & 0.7290 & 0 & 0.8052 & 3 & -1.85 & 0 & Unit root \\
\hline Malawi & 0.7724 & 1 & 0.4021 & 0 & -1.67 & 1 & Unit root \\
\hline Rwanda & 0.7447 & 0 & 0.8155 & 6 & -1.50 & 0 & Unit root \\
\hline Sudan & 0.8001 & 3 & 0.7435 & 21 & -1.45 & 5 & Unit root \\
\hline Senegal & 0.9833 & 1 & 0.9775 & 19 & -0.93 & 0 & Unit root \\
\hline Singapore & 0.8138 & 0 & 0.8450 & 3 & -1.52 & 0 & Unit root \\
\hline Thailand & 0.2538 & 0 & 0.1933 & 2 & -2.57 & 0 & Unit root \\
\hline South Africa & 0.6935 & 0 & 0.7300 & 3 & -1.85 & 0 & Unit root \\
\hline Zambia & 0.9919 & 0 & 0.9921 & 1 & -0.40 & 0 & Unit root \\
\hline Zimbabwe & 0.2322 & 1 & 0.2683 & 3 & -2.71 & 1 & Unit root \\
\hline
\end{tabular}

country recorded minimal economic growth in the period 1970 to 2000 . The command economic system from 1964 to 1990 under the one-party system contributed to this marginal growth as government intervention in the market and the nationalization of major industries affected their efficiency and as such most of them were loss making. Economic growth in 1970-1990 was mainly resource-driven through use of physical and human capital. The liberalization of the economy and the introduction of democracy in 1991 resulted in notable economic growth starting in the year 2000. The country's economic agenda of diversification and investment in agriculture as the center of economic development was taking shape. However, until today, Zambia's agriculture sector is still underdeveloped and is highly vulnerable to climatic changes. Despite the country's abundant land and water resources, agricultural productivity is below the regional average for Sub-Saharan Africa. Furthermore, the economy continues to be heavily reliant on copper, and the share of agriculture to GDP has been reducing since 1995. Despite the growth observed under the free market economy, Zambia continues to be a net importer of essential commodities and economic growth has been regressing just three years after the MIC classification. Foreign debt sustainability continues to be one of the major economic issues in 
the country, calling for better fiscal discipline and economic governance. Zambia recorded a government debt equivalent to 59 percent of the country's Gross Domestic Product in 2018.

\section{Conclusion}

The study has shown that Zambia's economic growth was affected by the country's economic systems in the period 1964-1990 and 1991 to 2018. During the command economy in the 1970s, growth was affected by high state intervention which saw the nationalisation of key institutions and enterprises across various sectors. This affected their profitability and output, despite the country's rich physical and human resources. The introduction of multiparty democracy and free market economic system after 1991 led to the recovery of the Zambian economy especially after the year 2000. While Zambia attained lower middle-income status in 2010, GDP per capita growth is already taking a downward trend and the country faces a risk of falling back to low-income status.

The study has shown that Zambia is at a high risk of falling in the MIT. Using the US as a benchmark country, Zambia's GDP per capita income has been diverging from that of the US for the entire study period spanning from 1960 to 2019. Out of the 18 sampled countries, only three have shown growth against the US, including Singapore, Thailand, and Botswana. To break from the MIT, Zambia should diversify its economy and shift from input led growth to growth based on economic efficiency. At lower middle-income level, the lack of sustained economic growth in Zambia is due to 1) the inability to identify new growth drivers at the middle-income stage, and 2) failure to institute the required political and institutional reforms to sustain growth at MIC level.

\section{Recommendations for Avoiding the MIT Given Zambia's Unique Context}

1) Zambia should identify and promote new sources of economic growth from both agriculture and secondary sectors. To fuel this, the country should promote innovations across the primary and secondary sectors by improving the country's industrial policy and the introduction of subsidies for innovations.

2) Given the shift in the drivers of economic growth from low to lower middle-income, Zambia should work at improving labor productivity through investment in education and technology to ensure that secondary sectors drive growth.

3) Zambia needs to increase investment in agriculture to ensure complete agriculture transformation. For a start, the government should guarantee at least $10 \%$ investment of its annual budget to agriculture in line with the Comprehensive Africa Agriculture Development (CAADP) target.

4) Given the current debt distress in the country, the government should minimise borrowing and rather strengthen local resource mobilization.

5) This investigation can be developed further. An econometric examination 
looking at the number of times Zambia has been caught in the MIT, and how recognizing those nations that have overcome the MIT from those that need to learn from Zambia.

\section{Conflicts of Interest}

The author declares no conflicts of interest regarding the publication of this paper.

\section{References}

Agenor, P.-R. (2016). Caught in the Middle? The Economics of Middle-Income Traps. Journal of Economic Surveys, 31, 771-791. https://doi.org/10.1111/joes.12175

Agenor, P.-R., \& Canuto, O. (2012). Middle-Income Growth Traps. World Bank Policy Research Working Paper No. 6210. https://doi.org/10.1596/1813-9450-6210

Aiyar, S., Duval, R., Puy, D., Wu, Y. Q., \& Zhang, L. M. (2013). Growth Slowdowns and the Middle-Income Trap. IMF Working Paper 6.

https://doi.org/10.5089/9781484330647.001

Albuquerque, E. D. (2019). Brazil and the Middle-Income Trap: Its Historical Roots. Seoul Journal of Economics, 32, 23-62.

Arezki, R., Fan, R. Y., \& Nguyen, H. (2019). Technology Adoption and the Middle-Income Trap: Lessons from the Middle East and East Asia. Policy Research Working Paper No. 8870, Washington DC: World Bank.

https://doi.org/10.1596/1813-9450-8870

Aviliani, A., Siregar, H., \& Hasanah, H. (2014). Addressing the Middle-Income Trap: Experience of Indonesia. Asian Social Science, 10, 163.

https://doi.org/10.5539/ass.v10n7p163

Bernard, A., \& Durlauf, S. (1996). Convergence in International Output. Journal of Applied Econometrics, 10, 97-108. https://doi.org/10.1002/jae.3950100202

Bukowski, M., Halesiak, A., \& Petru, R. (2013). Konkurencyjna Polska 2020. Deregulacjai-Innowacyjność. WarszawskiInstytutStudiówEkonomicznych.

https://polskie-zaklady-bukmacherskie.pl/?fid=17

Bulman, D., Eden, M., \& Nguyen, H. (2014). Transitioning from Low-Income Growth to High-Income Growth: Is There a Middle Income Trap? World Bank Policy Research Working Paper No. 7104. https://doi.org/10.1596/1813-9450-7104

Dieye, A. M. (2014). Want to Escape Africa's Middle-Income Trap? Avoid the "Jekyll and Hyde Syndrome”. Devex.

https://www.devex.com/news/want-to-escape-africa-s-middle-income-trap-avoid-the-j ekyll-and-hyde-syndrome-83764

Doner, R. F., \& Schneider, B. R. (2016). The Middle-Income Trap: More Politics than Economics. World Politics, 68, 608-644. https://doi.org/10.1017/S0043887116000095

Eichengreen, B., Park, D., \& Shin, K. (2012a). When Fast Growing Economies Slow Down: International Evidence and Implications for China. Asian Economic Papers, 11, 42-87. https://doi.org/10.1162/ASEP_a_00118

Eichengreen, B., Park, D., \& Shin, K. (2012b). From Miracle to Maturity: The Growth of the Korean Economy. Cambridge, Mass.: Harvard University Press for the Harvard Asia Center.

Farah, N. (2016). Evaluating Growth Slowdowns: Does Middle-Income Trap Exist (pp. 9-15)? Charleston, IL: Eastern Illinois University. 
Felipe, J., Abdon, A., \& Kumar, U. (2012). Tracking the Middle-Income Trap: What Is It, Who Is in It, and Why? https://doi.org/10.2139/ssrn.2049330

Felipe, J., Kumar, U., \& Galope, R. (2014). Middle-Income Transitions: Trap or Myth? Asian Development Bank Economics Working Paper Series, No. 421. https://doi.org/10.2139/ssrn.2558905

Flaaen, A., Ghani, E., \& Mishra, S. (2013). How to Avoid Middle-Income Traps? Evidence from Malaysia. Washington DC: World Bank. https://doi.org/10.1596/1813-9450-6427

Furuoka, F., Pui, K. L., Ezeoke, C., Jacob, R. I., \& Yaya, O. S. (2019). Growth Slowdowns and Middle-Income Trap: Evidence from New Unit Root Framework. MPRA Paper 98672, University Library of Munich, Germany. https://doi.org/10.1142/S0217590820500083

Gill, I. S., \& Kharas, H. (2007). An East Asian Renaissance: Ideas for Economic Growth. Washington, DC: World Bank. https://openknowledge.worldbank.org/handle/10986/6798 https://doi.org/10.1596/978-0-8213-6747-6

Im, F. G., \& Rosenblatt, D. (2013). Middle-Income Traps: A Conceptual and Empirical Survey. Policy Research Working Paper No. 6594, Washington DC: World Bank. https://doi.org/10.1596/1813-9450-6594

IMF (2016). Africa on the Move: Unlocking the Potential of Small Middle-Income States (pp. 3-4).

IMF (2019). 2019 Article IV Consultation Press Release, Staff Report, and Statement by the Executive Director for Zambia. Lusaka: IMF.

Ito, T. (2017). A New Financial Order in Asia: Will a RMB Bloc Emerge? Journal of International Money and Finance, 74, 232-257.

https://doi.org/10.1016/j.jimonfin.2017.02.019

Jones, C. I. (2002). Sources of U.S. Economic Growth in a World of Ideas. American Economic Review, 92, 220-239. https://doi.org/10.1257/000282802760015685

Kang, N., \& Paus, E. (2020). The Political Economy of the Middle Income Trap: The Challenges of Advancing Innovation Capabilities in Latin America, Asia and Beyond. The Journal of Development Studies, 56, 651-656. https://doi.org/10.1080/00220388.2019.1595601

Khan, R. (2019). Towards an Upper Middle-Income Economy. The Patriot.

Kharas, H., \& Kohli, H. (2011). What Is the Middle-Income Trap, Why Do Countries Fall into It, and How Can It Be Avoided? Global Journal of Emerging Market Economies, 3, 281-289. https://doi.org/10.1177/097491011100300302

Kim, L. (1997). Imitation to Innovation: The Dynamics of Korea's Technological Learning. Boston, MA: Harvard Business Press.

Konya, S., Karaçor, Z., \& Yardımci, P. (2018). The Middle Income Trap: An Empirical Evidence on the Turkish Economy. International Journal of Diplomacy and Economy, 4, 172-184. https://doi.org/10.1504/IJDIPE.2018.094091

Lee, J.-W. (2019). Convergence Success and the Middle-Income Trap. The Developing Economies, 58, 30-62. https://doi.org/10.1111/deve.12214

Lee, K., \& Li, S. (2014). Possibility of a Middle-Income Trap in China: Assessment in Terms of the Literature on Innovation, Big Business, and Inequality. Frontiers of Economics in China, 9, 370-397.

Leven, B. (2019). Middle-Income Trap: The Case of Poland. Business and Economics Research Journal, 10, 1029-1038. https://doi.org/10.20409/berj.2019.219

Mondi, L. (2016). South Africa Can Expect Zero Growth. Its Problems Are Largely Ho- 
memade. The Conversation.

Oxley, L., \& Greasley, D. (1997). Convergence in GDP Per Capita and Real Wages: Some Results for Australia and the UK. Mathematics and Computers in Simulation, 43, 429-436. https://doi.org/10.1016/S0378-4754(97)00028-1

Paprotny, D. (2021). Convergence between Developed and Developing Countries: A Centennial Perspective. Social Indicators Research, 153, 193-225. https://doi.org/10.1007/s11205-020-02488-4

Pritchett, L., \& Summers, L. (2014). Growth Slowdowns: Middle-Income Trap vs. Regression to the Mean. VOX CEPR's Policy Portal.

Robertson, P. E., \& Ye, L. (2013). On the Existence of a Middle-Income Trap. University of Western Australia Working Paper 13/12.

Solow (1956). A Contribution to the Theory of Economic Growth. The Quarterly Journal of Economics, 70, 65-94. https://doi.org/10.2307/1884513

Steinbach, R. (2019). Growth in Low-Income Countries, Evolution, Prospects, and Policies. Policy Research Working Paper 8949. https://doi.org/10.1596/1813-9450-8949

The Economist (2011). Beware the Middle-Income Trap: China's Roaring Growth Cannot Last Indefinitely. The Economist, 4-8.

Woo, W., Lu, M., Sachs, J., \& Chen, Z. (2012). A New Economic Growth Engine for China: Escaping the Middle-Income Trap by Not Doing More of the Same. London: Imperial College Press. https://doi.org/10.1142/8598

Zhu, M. (2016). Small Middle-Income Countries in Africa Need to Rethink Their Growth Strategy. Tralac. 